\title{
Hayrabolu'da Evsel Katı Atık Toplama Faaliyetleri Sonucu Oluşan Sera Gazlarının Tespiti ve Karşılaştırılması
}

\author{
Eyüp Nafiz KORKUT*1 (D) \\ 1İstanbul Büyükşehir Belediyesi, Çevre Koruma ve Kontrol Dairesi, , 34440, İstanbul, Türkiye
}

(Alınış / Received: 25.03.2019, Kabul / Accepted: 05.08.2019, Online Yayınlanma / Published Online: 30.08.2019)

\begin{abstract}
Anahtar Kelimeler
Evsel atık toplama,

Sera gazı emisyonu,

Küresel ısınma faktörü,

Evsel atık toplama aracl,

Atık yönetimi
\end{abstract}

Özet: Bu çalışmada Tekirdağ ilinin Hayrabolu ilçesine ait mahallelerde evsel atıkların toplanması sonucu oluşan sera gazı miktarları araştırılmıștır. Çalışma 2017 senesinin Mayıs ayı boyunca yapılmıştır. Evsel atıkların toplanması için kullanılan araçların yaptıkları toplam mesafeler ve topladıkları atık miktarları ayrıntılı olarak tespit edilmiştir. Bu tespitler kullanılarak her bir toplama aracının meydana getirdiği sera gazı miktarları $\mathrm{CO}_{2}$ eşdeğeri olarak hesaplanmıştır. Küresel ısınma faktörü olarak tanımlanan ve her bir toplama aracı için 1 ton toplanan atık başına oluşan $\mathrm{CO}_{2}$ eşdeğerleri hesaplanmıştır. Sonuçta ilçede evsel atık toplamaya bağlı her mahallede ve toplamda meydana gelen sera gazı miktarları hesaplanmıștır. Buna göre Hayrabolu'da toplamda aylı 18,68 ton $\mathrm{CO}_{2}$ eșdeğeri tespit edilmiștir. Ayrıca, aylık ortalama küresel ısınma faktörü $13,30 \mathrm{~kg} \mathrm{CO}$ eş/ton-atık olarak hesaplanmıştır. Son olarak tespit edilen bu değerler literatürdeki benzer çalışmalarla karşılaştırılmıştır.

\section{Determination and Comparison of Greenhouse Gases As A Result of Household Solid Waste Collection in Hayrabolu}

\section{Keywords}

Household waste collection, Greenhouse gas emission, Global warming factor, Household waste collection vehicle,

Waste management

\begin{abstract}
Tekirdağ is a city that located in Northwest of Turkey. Hayrabolu is one the sub districts of Tekirdağ. Total greenhouse gas emissions and average global warming factor for Hayrabolu and its districts were estimated as a result of household waste collection activities. This study was carried out during May of 2017. The amount of distance travelled and disel fuel consumed by waste collection vehicles were recorded. These recorded values were used for the calculation and estimation of greenhouse gases amounts. The quantified disel fuel consumptions for each waste collection vehicles were evaluated separately in order to compare with each other. Total monthly greenhouse gas emission for Hayrabolu was estimated as 18,68 tons $\mathrm{CO}_{2}$-equivalent. On the other hand, the average monthly global warming factor was calculated as $13,30 \mathrm{~kg} \mathrm{CO}_{2}$-equivalent per ton of waste collected. Lastly, these estimated values were compared with the values in the literature.
\end{abstract}

\section{Giriş}

Özellikle son 20-30 senelik süreçte, fosil yakıtların kullanımına bağlı atmosfere salınan sera gazları (GHG) ve diğer kirleticiler artmaktadır. Bu gazların artışı, küresel ısınma olarak isimlendirilen bütün dünya yüzeyinin ısınmasına sebep olmaktadır. Bu artış aynı zamanda bölgesel ve küresel iklimlerin beklenenin dışında soğuk veya sıcak olmasına ve sürelerinin değişimine sebep olmaktadır. Günümüzde hala şehir içi insan ve yük taşımacılığı faaliyetlerinde fosil yakıtlara bağlılık yüksek oranda devam etmektedir. Evsel katı atıkların toplanıp taşınması, yük taşımacılığı sınıfında değerlendirilmekte olup çoğunlukla fosil yakıtların (dizel) kullanımı ile gerçekleştirilmektedir. $\mathrm{Bu}$ yakıtların kullanımı, atmosfere verilen sera gazları ve diğer kirlilik parametrelerinin artmasına sebep olmaktadır. Simonetto ve Borenstein [1] ve Iriarte ve diğ. [2] evsel atık toplama ve transferinin hala çalışılması ve optimize edilmesi gereken bir araştırma konusu olduğunu, sonuçta iș verimliliğini artıracağı ve yakıt tasarrufu sağlayacağını, buna bağlı olarak da, sera gazlarının azaltımına fayda sağlayacağını ortaya koymuşlardır. Bunun temini için öncelikle bütün şehirler ve yerleşimler için evsel katı atık toplama, 
transfer ve taşıma faaliyetlerinden kaynaklanan GHG'lerin tespit edilmesi, gerekli optimizasyon ve iyileştirmeler yapılması gerekmektedir.

Katı atıkların toplanması, transferi ve taşınması neredeyse tamamen dizel yakıt tüketen araçlarla yapılmaktadır. Dizel yakıtın hem temini hem de tüketiminden kaynaklanan GHG oluşturmaktadır. Her bir ton toplanan katı atık için tüketilen dizel yakıt miktarı bölgede toplanan katı atığın miktarına, toplama alanına, toplama araçlarının türüne ve hacmine, boşaltma noktasının mesafesine ve araç sürücülerinin araçları nasıl kullandıklarına göre değişim göstermektedir. Dizel yakıt tüketimi, toplama aracının hızlanmasında, yavaşlamasında, sabit hızla seyrinde ve toplama noktalarında sıkıştırma yaparken farklılı göstermektedir. Aynı zamanda toplanan atığın yoğunluk ve toplama aracının hacmi de yakıt tüketimi ve dolayısıyla GHG oluşumlarını etkilemektedir. Bu konuda yapılacak optimizasyon çalışmaları, özellikle gidilen yolun azaltılması ve araç doluluklarının artırılması; işçilik, zaman ve yakıttan ekonomik tasarruf sağlayarak GHG azaltımına katkıda bulunacaktır.

Katı atıkların toplanması ve transferine bağlı olarak oluşan GHG tahminleri konusunda birçok çalışma mevcuttur. 1 ton ıslak katı atığın toplanıp, transferi ve taşınması sonucu oluşan $\mathrm{kg}$ cinsinden $\mathrm{CO}_{2}$ eşdeğeri Eisted ve diğ. [3] tarafından küresel ısınma faktörü (GWF) olarak tarif edilmiştir. Eisted ve diğ. [3] ve Larsen ve diğ. [4] Danimarka'da bazı belediyelerin 1 ton katı atığın toplanıp $20 \mathrm{~km}$ mesafeye taşımasından oluşan GWF'lerin 9-17 kg CO 2 -eş ( $\mathrm{kg} \mathrm{CO} 2$ eşdeğeri), 150 km'ye taşımasından oluşan GWF'lerin ise 24-44 $\mathrm{kg} \mathrm{CO}_{2}$-eş arasında değiştiğini hesaplamışlardır. Kullanılan bu küresel ısınma faktörü şehirlerin katı atık toplama, transfer ve taşımada kullanabilecekleri karşılaştırılabilir bir ifade olarak kullanılması büyük bir öneme sahiptir ve kolaylık sağlamaktadır. Bu faktörün tespiti İstanbul için ilçe bazında Korkut ve diğ. [5] tarafindan yapılmış ve 4,60-15,20 kg CO 2 -eş arasında değiştiği hesaplanmıştır. $\mathrm{Bu}$ çalışmaya benzer olarak diğer il ve ilçelerin bu faktörleri kendileri için tespit etmesi, karşılaştırması ve minimize etmesi için gerekli çalışmaları biran önce yapmaları gerekmektedir. Günümüzde kullandığımız GHG azaltımı ya da karbon ayak izi olarak isimlendirilen parametrelerin azaltımı konusunda rekabet etmek, çevre, verimlilik ve hava kalitesinin iyileştirilmesine en yüksek faydayı sağlayacaktır.

Toplama araçlarının yakıt tüketimi ve buna bağlı emisyonlar toplama araçlarının özelliklerine, toplama bölgesinin nüfus yoğunluğu ve coğrafi özelliklerine ve toplanan atıkların yoğunluklarına göre farklılıklar gösterebilmektedir. Larsen ve diğ. [4], evsel atık, geri kazanılmış camlar ve geri kazanılmış kağıt atıkları taşıyan toplama araçlarının şehir içi ve şehir dışı faaliyetlerinden kaynaklanan dizel yakıt tüketimlerini hesaplamışlar ve 1 ton toplanan atık için, şehir içi ve şehir dışı yakıt tüketiminin 1,4 lt ile 10,1 lt dizel aralığında değiştiğini göstermişlerdir. Larsen ve diğ. [4] ayrıca, geri kazanılmış kağıt toplanması için harcanan yakıt tüketimini incelemişler ve 1 ton geri kazanılmış kağıdın toplanıp tesise getirilmesi için harcanan dizel yakıt miktarının 3,7 lt ile 4,9 lt arasında değiștiği tespit etmiş ve bu miktar yakıtların tüketilmesi sonucu oluşan GWF değerlerinin 11,5 kg $\mathrm{CO}_{2}$-eş ile $15,7 \mathrm{~kg} \quad \mathrm{CO}_{2}$-eş arasında değiştiğini hesaplamışlardır. Spielman ve diğ. [6] farklı araçlarla taşınan 1 ton katı atığın $1 \mathrm{~km}$ mesafeye taşınması için GWF'ün 0,091 ile $0,0557 \quad \mathrm{~kg} \quad \mathrm{CO}_{2}$-eş olduğunu belirlemişlerdir. Diğer bir çalışmada Spielman [7] 3,520 ton katı atık tașıyan toplayıcı araçlar için $\mathrm{CO}_{2}$ emisyonunun her $\mathrm{km}$ için 0,5716 kg, 20-28 ton taşıyan araçlar için $\mathrm{CO}_{2}$ emisyonunun her $\mathrm{km}$ için $0,7793 \mathrm{~kg}$ ve 28 tondan daha fazla yük taşıyan araçlar içinse her $\mathrm{km}$ için $\mathrm{CO}_{2}$ emisyonunun $0,8913 \mathrm{~kg}$ olduğunu tespit etmişlerdir.

Larsen ve diğ. [8] 1 ton evsel katı atı̆̆ın toplanıp taşınmasından kaynaklanan GWF'ün $30 \mathrm{~kg} \mathrm{CO}$-eş olduğunu belirlemişlerdir. Az miktardaki atıkların uzun mesafelere düşük kapasiteli araçlarla taşınması büyük emisyonlara sebep olmaktadır. $\mathrm{Bu}$ yüzden optimum transfer istasyonu yerlerinin tespit edilerek inşa edilmesi emisyon azaltılmaları için önemlidir. Smith ve diğ. [9], Fisher [10] ve Skovgaard ve diğ. [11] Avrupa'da evsel katı atıkların toplama ve taşınmasının meydana getirdiği GWF'lerinin 5-17 kg $\mathrm{CO}_{2}$-eş/ton-atık olduğunu belirlemișlerdir. Salhofer ve diğ. [12] kağıt ve bazı plastik türlerinin taşınması için bazı senaryolar oluşturmuş ve GWF'lerin 13-22 $\mathrm{kg} \mathrm{CO}$-eş/ton-atık arasında olduğu hesaplanmıştır. Geri kazanılmış Polietilen filmlerin 1 tonunun toplanıp taşınmasından kaynaklanan GWF'ün 12-137 kg $\mathrm{CO}_{2}$-eş arasında geniş bir aralıkta değiştiğini belirlemişlerdir. Hesaplanan bu değerlerin geniş bir aralıkta değişiyor olması taşıma mesafesindeki farklılıklar ve toplanıp taşınan malzemenin yoğunluğuna bağlıdır. Mesafe arttıkça ve taşınan malzemenin yoğunluğu düştükçe GWF artmaktadır.

Toplama, transfer ve taşımadan kaynaklanan küresel ısınma faktörü her bir ton toplanan katı atık için genelde $50 \mathrm{~kg} \mathrm{CO}$-eş'nin altındadır. Fakat düşük yoğunluklu atıkların taşındığı ve taşıma mesafelerinin uzak olduğu örneklerde, bu değerler yüksek olabilmektedir. ICF Consulting [13] ve Metcalfe [14] toplama ve taşımanın veriminin, bir defada çok miktarda atık taşınması ve yeni ekipmanların kullanılması ile artırılabileceğini göstermişlerdir. Diğer taraftan, Facanha ve Horvath [15] ve Iriarte ve diğ. [2] araç türü ve aerodinamik özelliklerin, çalışma bölgesine ait topoğrafyanın, hava kalitesinin, iyi ve verimli sürüş tekniklerinin oluşan emisyonlar ve yakıt tüketimleri üzerine etkilere göstermişlerdir. Buna benzer çalışmalar, GHG emisyonları ve yakıt tüketimlerinin, toplama yapılan bölgenin topografik durumu, araç tipi ve atık karekterine bağlı olduğunu ortaya koymaktadır. Her bölgenin kendine özgü coğrafi yapısı, farklı atık 
karekterleri ve kullandı̆̆ı araçların farklılı̆̆ından dolayı toplama ve taşımadan kaynaklanan yakıt tüketimleri ve GHG tespitleri ayrıca incelenmeli ve birbirleri ile karşılaştırılmalıdır.

Simonette ve Borenstein [1] SCOLDSS adı verilen karar verme destek sistemini kullanarak katı atık toplamayı planlamışlardır. Bu bilgisayar programında oluşturulan karar destek hesaplamalarını Brezilya'nın Porto Alegra şehri için gerçekleştirmişlerdir. Bu programın kullanımı ile toplama araçlarının gittiği mesafelerde \%8,82 azalma ve yapılan haftalık sefer sayısında da \%17,89 azalma sağlanmıştır. Dolayısıyla bu direk emisyon azaltımına karşılık gelmektedir. Iriarte ve diğ. [2] yoğun nüfuslu Barselona metropol bölgesi için 3 farklı atık toplama sisteminin potansiyel çevre etkilerini hayat dönüşün değerlendirme (LCA) yöntemini kullanarak yapmışlardır. $\mathrm{Bu}$ konuda hazırlanıp çalışılan senaryolarda, eğer transfer istasyonu ile depolama sahası arasındaki mesafe $11 \mathrm{~km}$ den fazla ise atık taşıma, toplamadan \%50 daha fazla yakıt tüketimi dolayısı ile daha fazla emisyon oluşturmaktadır. Gidilen mesafe ve sefer sayısında azaltım sağlanması, verimliliği artıracak ve dolayısı ile GHG gazlarının azaltımını sağlayacaktır. Benzer çalışmalar, bir şehrin atık toplama bilgilerini kullanılarak modelleme yapılmasına ve gelecek için tahminler yapılarak karşılaștırmalar yapılmasına firsat verecektir. Bu ileriye dönük yapılacak çalışmalarda büyük kolaylık sağlayacaktır. Aynı zamanda bu modellerin kullanımı hem yakıt tasarrufu sağlayacak hem de GHG emisyonlarını azaltma yönünde yapılacaklar konusunda öngörülerde bulunacaktır. Jaunich ve diğ. [16],[17] iki farklı şehrin verilerini kullanarak mekanistic toplama modeli geliştirmiş ve bu modeli diğer bir şehre uygulayarak doğrulamışlardır. Bu modelde gelecekteki nüfus değişiklikleri, atık miktarındaki değişiklikler, geri dönüşüm uygulamalarındaki faklılıklar gözönüne alınarak, o şehre has model oluşturulmuş ve geleceğe dönük yakıt tüketimlerinin tespiti ve GHG tahminleri yapılmış ve bu gazların azaltımı konusunda yapılabilecekler tartışılmıştır. Aynı model İstanbul için uygulanmış ve Korkut ve diğ. [5] makalesinde ayrıntılı olarak ele alınmıştır. Ayrıca aynı makalede, İstanbul'da 2015 senesi için katı atıkların ilçeler bazında toplanmasından kaynaklanan GHG ve GWF miktarları ve kişi başına oluşan $\mathrm{kg} \mathrm{CO}_{2}$ eşdeğerleri hesaplanmıştır. $\mathrm{Bu}$ değerlerin İstanbul gibi bir metropol için ilçeden ilçeye, nüfus yoğunluğu, ilçenin coğrafi büyüklüğü ve ilçenin ticari ve endüstriyel faaliyet yoğunluklarına bağlı olarak değişim gösterdiği ortaya konmuştur.

Bu çalışma, Korkut ve diğ.'nin [5] İstanbul ilçeleri için yaptığı emisyon tespiti çalışmasına benzer olarak Türkiye'nin birçok ilçesine nüfus ve yüzeysel alan olarak benzerlik gösteren Tekirdağ ilinin Hayrabolu ilçesi için Mayıs 2017 ayı boyunca yapılmıștır. Bunun için öncelikle her bir atık toplama aracının aylık yaptığı mesafe, aylık tükettiği dizel yakıt miktarı, ve topladığı atık miktarı tespit edilmiş ve araç bazında GHG ve GWF değerleri hesaplanmıștır. Her aracın oluşturduğu GHG'ler toplanarak ilçe için aylık toplam emisyon hesaplanmıştır. Bunların yanı sıra her araç için topladığı aylık atık miktarları değerlendirilerek her aracın olușturduğu GWF'ler hesaplanmıștır. Ayrica genel toplamda oluşan GHG değerinin toplam toplanan atık miktarına bölünmesiyle ortalama GWF değeri hesaplanmıștır. Ortalama GWF değerinin her mahalleden toplanan aylık atık miktarı ile çarpılması sonucu her mahallenin olușturduğu GHG miktarları hesaplanmıștır. Mahalle bazında hesaplanan GHG değerlerinin mahalle nüfusuna bölünmesiyle kişi başına ortalama GHG'ler hesaplanmıştır.

\section{Materyal ve Metot}

\section{1. Çalışma bölgesinin tanımlanması}

Hayrabolu, Tekirdağ ilinin nüfus bakımından sekizinci büyük ilçesi olup, toplam nüfusu 32.157 olup yüzey alanı $990 \mathrm{~km}^{2}$ 'dir. Nüfus yoğunluğu yaklaşık 32 kişi $/ \mathrm{km}^{2}$ 'dir. Tekirdağ, büyükșehir belediyesi olmadan önce Hayrabolu ilçesinin merkeze ait 4 mahallesi, 2 beldesi ve 46 köyü mevcuttu. Bu şehir, büyükşehir belediyesi olunca Hayrabolu ilçesinin 4 merkez mahallesine ilaveten 2 belde ve 46 köyde mahalle statüsüne kavuşarak ilçenin mahalle sayısı 52'ye çıkmıştır. Aydınevler, Hisar, İlyas ve Kahya merkez mahalleleri ve eski belde olan Çerkezmüsellim ve Şalgamlı mahalleleri ilçenin nüfusunun büyük bir kısmını oluşturmaktadır. Bu 6 mahallenin toplam nüfusu 21.868 'dir. Eski köy olan diğer 46 mahallenin toplam nüfusu ise 10.289 'dir. Merkez mahallelerde genelde ticaret ve sanayi iș kolu olarak yaygınken diğer mahallelerde tarım ve hayvancılık ağırlıktadır.

Çalışma süresi olan Mayıs 2017'ye ait mahallelerin toplam nüfusları, yüzeysel yerleşim alanları, atık alınan nokta sayıları, atık toplama sıklıkları ve aylık toplanan atık miktarları tespit edilmiștir. İlçe genelinde mahallelerden toplanan evsel atıklar Hisar mahallesinde bulunan transfer istasyonuna taşınmaktadır. Transfer istasyonunda daha geniş hacimli araçlara yüklenen evsel katı atıklar Tekirdağ'ın diğer bir ilçesi olan Süleymanpaşa'da bulunan düzenli depolama sahasına bertaraf edilmek üzere taşınmaktadır. Bu çalışmada transfer istasyonu ile depo sahası arasındaki taşıma değerlendirilmemiş, sadece evsel katı atık toplamadan kaynaklanan emisyonlar hesap edilmiştir.

Hayrabolu ilçesinde özellikle geri kazanımın en yüksek tutulması için birçok çalışma uygulamaya konulmuştur. Geri kazanım çalışmaları özellikle şehir merkezinde ağırlık kazanmıştır. Bu çalışmalar hem yakıt tasarrufu hem de emisyon azaltımı için fayda sağlayacaktır. Geri kazanım faaliyetleri genelde okullar, alışveriş merkezleri ve kamu binalarında 
yoğunluk kazanmaktadır. Fakat geri kazanım ülkenin diğer birçok şehrinde olduğu gibi yeterli seviyeye ulaşmamıștır. Yetersiz geri kazanım hem lüzumsuz depo sahası kullanımı artırmakta hem de geri kullanılabilecek malzemelerin değerlendirilmesine sebebiyet vermektedir. Geri dönüşün miktarları konusunda elde edilen veriler yetersiz olduğu için bunların GHG emisyonlarına etkisi konusunda yeterince analiz ve değerlendirme yapılmamıștır.

\subsection{Atık toplama faaliyetleri}

Belediye hizmetleri içinde yer alan katı atık toplama hem belediye bütçelerde önemli masraflara hem de yüksek miktarda fosil yakıtların kullanımına yol açmaktadır. Fosil yakıtların kullanımı sonucunda sera gazı emisyonları oluşmaktadır. Evsel katı atıkların toplanıp transfer istasyonları veya depo sahalarına taşınması genelde belediyelerin alt yüklenicilere ihale yoluyla belli süreler için sözleşme ile yaptırdıkları hizmetlerdir. Tekirdağ ilinin bir ilçesi olan Hayrabolu'da evsel katı atıkların toplama işlemi alt yüklenici bir şirket tarafından gerçekleştirilmektedir.

$\mathrm{Bu}$ çalışmada toplama, mahallelerdeki sokak ve caddelerden konteynerlerin içindeki katı atıkların toplama aracına mekanik kollar vasıtasıyla otomatik olarak boşaltılması olarak tanımlanmaktadır. Toplama mesafesi olarak toplama aracının garajdan çıkıp ilk toplama noktasına varışı arasındaki mesafe, ilk katı atık toplama ile son katı atık toplama arasındaki gidilen mesafe, son toplama noktasından transfer istasyonu ya da depolama sahasına kadar gidilen mesafe ve boşaltım sonrası transfer istasyonundan ya da depo sahasından yeni bir toplama güzergahı ya da garaja kadar gidilen mesafe olarak tanımlanmıştır. Bu aynı zamanda bir sefer sayısına karşılık gelmektedir.

Toplama araçlarının topladıkları katı atıkları aktarma istasyonunda daha büyük hacimli taşıma araçlara boşaltması, aktarma ya da transfer olarak tanımlanır. Toplanan evsel atıklar ilçenin merkez Hisar mahallesinde bulunan transfer istasyonunu getirilmektedir. Buradan daha geniş hacimli taşıma araçlarına yüklenen atıklar Tekirdağ’ın diğer bir ilçesi olan Süleymanpaşa'da bulunan düzenli depolama sahasına taşınmaktadır. Büyük hacimli taşıma araçları genelde 4 veya 5 toplama aracının transfer istasyonuna getirdiği atıkları tek seferde depolama sahasına taşımaktadır. Hayrabolu Hisar mahallesinde bulunan transfer istasyonu ile Süleymanpaşa ilçesindeki düzenli depo sahası arasındaki mesafe 33 km'dir. Bu araçlar transfer istasyonu ile depolama sahası arasında sürekli seferler yapmaktadır.

Toplama araçlarının yakıt kullanımları, bölgenin topografik durumu, araç tipi, şoförün aracı kullanım şekli, trafik yoğunluğu, konteynerlerin boşaltılması sırasında harcanan zamana göre değişim göstermektedir. Korkut ve diğ. [5], İstanbul için toplama araçlarının ortalama km için harcadıkları dizel miktarının 0,5 lt olduğunu, ilçe belediyeleri temizlik işleri müdürlükleri ve İstanbul Büyükşehir Belediyesi Atık Yönetimi Müdürlüğünün tespitlerine dayandırarak vermişlerdir. Hayrabolu ilçesi için bu çalışma süresi boyunca gerçek tüketilen yakıt miktarları kayıt edilmiş ve hesaplamalarda kullanılmıștır.

Atık toplama faaliyetleri Hayrabolu ilçesinde Mayıs 2017 ayı boyunca incelenmiştir. Bu sürece ait atık toplama araç sayıları, araçların yaptığı sefer sayıları, araç bazında aylık toplanan atık miktarları, her aracın aylık yaptığı mesafe ve harcadıkları aylık dizel yakıt miktarları tespit edilmiştir. Ayrıca ilçenin mahalle nüfusları, yüzeysel yerleşim alanları, mahallelerden aylık toplanan atık miktarları, toplama nokta sayıları ve diğer veriler Hayrabolu Belediyesi tarafindan temin edilmiştir.

Çalışma süresi içinde, katı atık toplama sıklığı şehir merkez mahallelerinde her gün, eski belde olan Çerkezmüsellim ve Şalgamlı mahallelerinde haftada 3 veya 4 sefer ve eskiden köy olan diğer 46 mahallede de haftada bir sefer olarak gerçekleştirilmiştir. $\mathrm{Bu}$ çalışma süresi boyunca atık toplamada kullanılan araçların kapasiteleri $5 \mathrm{~m}^{3}$ ile $13 \mathrm{~m}^{3}$ arasında değișmiş ve 1 adet $5 \mathrm{~m}^{3}, 1$ adet $6 \mathrm{~m}^{3}, 3$ adet $7 \mathrm{~m}^{3}$ ve 5 adet $13 \mathrm{~m}^{3}$ lük toplama aracı kullanılmıștır. Toplama genelde taşıma ve işçilik yoğun bir hizmet olduğu için, bu ilçede de genelde bütün atık toplama çalışmalarında olduğu gibi araçların her seferi için bir şoför ve iki toplama personeli bulundurulmuştur.

İlçe merkez mahallelerinde yaşayan insanlar apartman ve müstakil konutlarda, diğer mahallelerde ise çoğunlukla müstakil evlerde ikamet etmektedirler. Genelde günlük olușturdukları katı atıkları cadde ve sokaklara belediye tarafından yerleştirilen $\quad 800 \quad$ lt'lik konteynerlere bırakmaktadırlar. Bırakılan konteyner sayıları mahallelerin nüfus ve yoğunluğuna göre değișim göstermektedir. Düşük nüfuslu mahallelerde konteynerler orda yaşayan insanların tespit ettikleri noktalara belediye tarafından yerleştirilmiştir.

İlçenin 4 merkez ve eski belde olan 2 mahallesinde atık alınan nokta sayısı 87 ile 391 arasında değişmekte olup toplamda 1204 atık toplama noktasından 1058,2 ton/ay atık toplanmıștır. Eski köy niteliğindeki yeni 46 mahallede ise toplam da 887 atık toplama noktası bulunmakta ve toplama nokta sayısı mahalleye göre 6 ile 54 arasında değişmektedir. Genelde bu mahallelerde toplama noktası sayısı 10 ile 20 civarındadır. $\mathrm{Bu}$ mahallelerden aylık toplam 316 ton atık toplanmıştır.

$\mathrm{Bu}$ çalışmada transfer istasyonu ile depo sahası arasında yapılan taşıma işlemi GHG hesaplamada göz önünde bulundurulmamıș, sadece cadde ve sokaklardan toplanan katı atıkların transfer istasyonuna getirilmesi sonucu oluşan GHG değerleri ve buna bağlı GWF'ler hesaplanmıştır. 


\subsection{GHG, GWF ve kişi başına $\mathrm{CO}_{2}$-eş hesabı,}

Hayrabolu da atık toplama faaliyetleri için tüketilen yakıt ve buna karşsı oluşan GHG emisyonları ve GWF değerleri Şekil 1. deki akım şeması kullanılarak hesap edilmiştir.

2017 yılı Mayıs ayı süresince evsel katı atık toplama faaliyetleri için toplama araçları tarafından yapılan aylık sefer sayıları, topladıkları aylık atık miktarları, toplam aylık yaptıkları mesafeler ve tükettikleri dizel yakıt miktarı GHG ve GWF hesaplamalarında kullanılmak üzere kaydedilmiştir. İlaveten aynı dönemde ilçesinin mahalle nüfusları ve her mahalleden toplanan atık miktarları tespit edilmiştir. $\mathrm{Bu}$ değerler kullanılarak her toplama aracının oluşturduğu GHG emisyonları ve GWF değerlerini hesaplanmıştır. Kullanılan toplama araçlarının toplam aylık tükettikleri dizel yakıt miktarları ve topladıkları aylık toplam atık miktarları hesaplanarak bu ilçenin toplamda oluşturduğu GHG değerleri ve ortalama GWF değeri hesaplanmıștır. Mahalle nüfusları kullanılarak en son kişi başına oluşan GHG emisyonları hesaplanmıştır.

Her toplama aracının bir ay boyunca tükettiği yakıt miktarı tespit edilmiștir. Fruergaard ve diğ. [18] 1 lt dizel yakıtın temini için $0,5 \mathrm{~kg} \mathrm{CO}$-eş ve yakılması sonucu olarak da $2,7 \mathrm{~kg} \mathrm{CO}_{2}$-eş emisyon oluştuğunu, toplamda da $3,2 \mathrm{~kg} \mathrm{CO}_{2}$-eş emisyon oluştuğunu rapor etmişlerdir. Daha sonra her aracın bir ay boyunca tükettiği dizel yakıt miktarları $3,2 \mathrm{~kg} \mathrm{CO}_{2}$-eș.lt ${ }^{-1}$ ile çarpılarak her aracın oluşturduğu GHG emisyonları hesaplanmıștır. Toplam 10 adet toplama aracının bir ay boyunca oluşturdukları GHG değerleri birbirleri ile toplanarak Hayrabolu ilçesinin atıklarını toplamak için meydana gelen toplam aylık GHG emisyonu hesaplanmıștır. Bu arada her aracın bireysel olarak oluşturduğu GHG miktarları aylık topladıkları atık miktarına bölünerek her aracın meydana getirdiği GWF değerleri hesaplanmıştır. Ortalama bir GWF bulmak için araçların faaliyetlerinden meydana gelen toplam aylık GHG değeri toplam aylık toplanan atık miktarı bölünerek bulunmuştur. Bu değer diğer literatür değerleri ile karşılaştırma bakımından önemlidir.

Diğer taraftan her mahallenin toplam yüzeysel yerleşim alanı, nüfusu, aylık toplanan atık miktarı, atık alınan nokta sayısı, kişi başına oluşturduğu atık miktarları tespit edilmiştir. Araçların oluşturduğu ortalama GWF miktarları her mahallede toplanan atık miktarı ile çarpılarak her mahallenin atık toplamak için meydana getirdiği GHG miktarları hesaplanmıştır. Ayrıca her mahallede kişi başına oluşan GHG miktarı mahalleye ait GHG değerinin mahalle nüfusuna bölünmesiyle bulunmuștur.

\section{Bulgular}

Hayrabolu ilçesi merkez ve diğer mahallelerinde atık toplama faaliyetlerinde kullanılan toplama araçları Mayıs 2017 ayı boyunca araştıılmıștır. Bu araştırma süresi boyunca kullanılan araçların sayı ve atık toplama hacimleri Tablo 1.de verilmiştir. Bunun yanında, bir ay süresince her aracın toplam sefer sayısı, toplam yaptığı mesafe, toplam topladığı atık miktarı ve toplam tükettiği dizel yakıt miktarı ayrı ayrı tespit edilmiş ve yine aynı tabloda verilmiştir. Her aracın sefer başına topladığı atık miktarları ve sefer başına yapılan mesafeler ortalama olarak hesaplanmış ve aynı tabloda verilmiştir. Her aracın aylık oluşturduğu toplam GHG miktarları ve her aracın aylık ortalama oluşturduğu GWF miktarları hesaplanmış ve aynı tabloda verilmiştir.

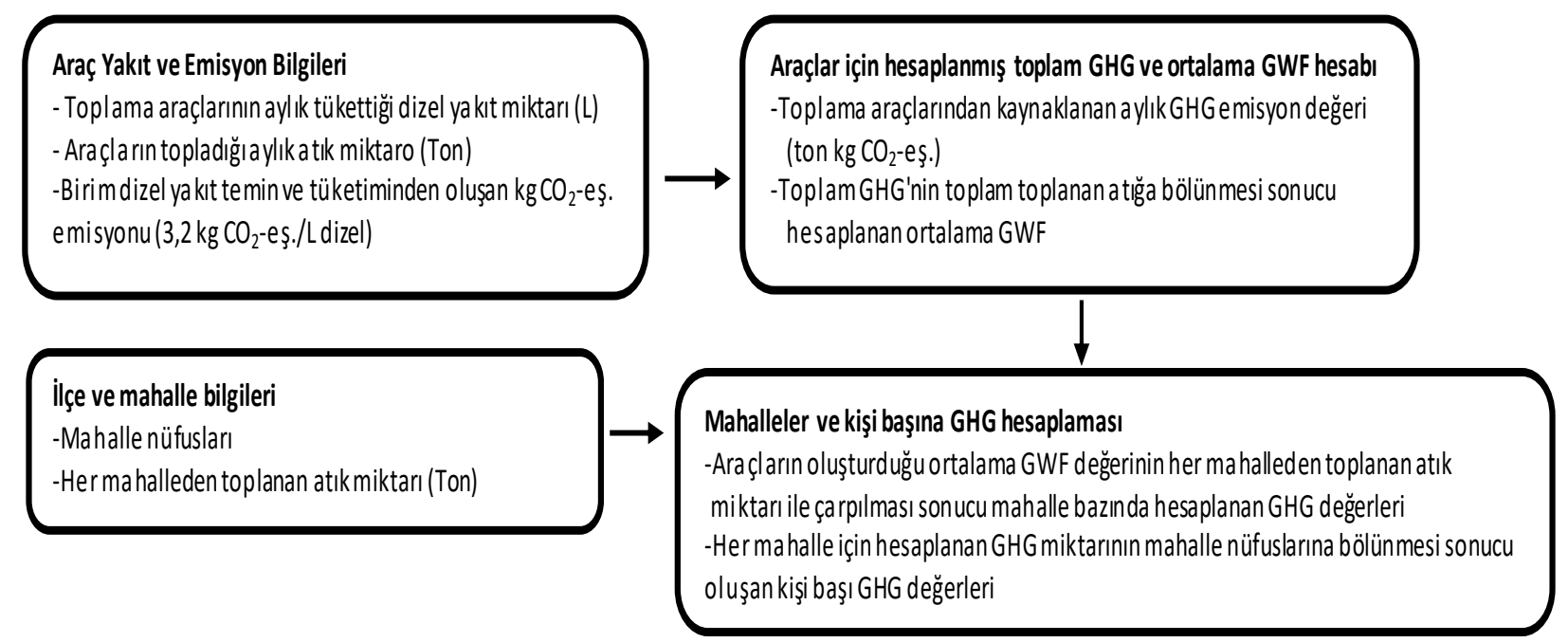

Şekil 1. Sera gazı ve küresel ısınma faktörü hesabı için akım şeması 
Tablo 1. Evsel atık toplama araçlarına ait detaylı bilgiler

\begin{tabular}{ccccccccccc}
\hline $\mathbf{1}$ & $\mathbf{2}$ & $\mathbf{3}$ & $\mathbf{4}$ & $\mathbf{5}$ & $\mathbf{6}$ & $\mathbf{7}$ & $\mathbf{8}$ & $\mathbf{9}$ & $\mathbf{1 0}$ & $\mathbf{1 1}$ \\
\hline 1 & 13 & 50 & 2083,90 & 330 & 835,39 & 6,6 & 41,7 & 2,52 & 2,67 & 8,10 \\
\hline 2 & 13 & 50 & 1782,90 & 240 & 827,85 & 4,8 & 35,7 & 3,42 & 2,65 & 11,04 \\
\hline 3 & 13 & 50 & 2047,55 & 225 & 1019,92 & 4,5 & 41,0 & 4,55 & 3,26 & 14,49 \\
\hline 4 & 13 & 30 & 871,50 & 75 & 363 & 2,5 & 29,1 & 4,88 & 1,16 & 15,47 \\
\hline 5 & 7 & 50 & 1505,05 & 90 & 463,84 & 1,8 & 30,1 & 5,18 & 1,48 & 16,44 \\
\hline 6 & 7 & 50 & 2231,25 & 110 & 647 & 2,2 & 44,6 & 5,88 & 2,07 & 18,82 \\
\hline 7 & 5 & 20 & 463,40 & 35 & 70 & 1,75 & 23,2 & 2,00 & 0,22 & 6,29 \\
\hline 8 & 13 & 50 & 1547,90 & 210 & 550 & 4,2 & 31,0 & 2,65 & 1,76 & 8,38 \\
\hline 9 & 7 & 50 & 1544,30 & 90 & 431 & 1,8 & 30,9 & 4,80 & 1,38 & 15,33 \\
\hline Toplam & & & & & & & & & & \\
\hline
\end{tabular}

Ort.

13,30

1. Araç No, 2. Kasa Hacmi $\left(\mathrm{m}^{3}\right)$, 3. Ortalama Aylık Sefer Sayısı, 4. Ortalama Aylık Yaptığı Mesafe (Km), 5. Ortalama Aylık Topladığı Atık Miktarı (Ton), 6. Harcadığı Toplam Yakıt (Lt), 7. Sefer Başına Toplanan Atık (Ton/sefer), 8. Sefer Başına Alınan Yol (Km/sefer), 9. Birim Atık Taşınması için Harcanan Yakıt (L/ton.km), 10. Toplam GHG (ton $\mathrm{CO}_{2} . \mathrm{eş}$ ), 11. GWF (kg $\mathrm{CO}_{2 .}$.eş/ton atık)

5 ile $13 \mathrm{~m}^{3}$ arasında değișen evsel atık taşıma hacimlerine sahip toplam 10 araç bir aylık çalıșma süresi boyunca 400 sefer yaparak toplam 1405 ton atık toplamışlardır. Sefer başına ortalama olarak yaklaşık 3,5 ton atık toplanmıştır. Toplanan atıkların

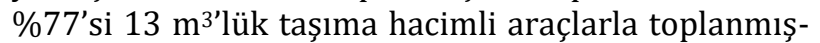
tır. Her aracın topladığı toplam aylık miktarın toplam sefer sayısına bölünmesiyle ortalama sefer başına toplanan atık miktarları hesaplanmıştır. Tablo 1'in yedinci kolonunda her aracın sefer bașına tașıdı ğ ortama atık miktarları verilmektedir. 1 nolu 13 $\mathrm{m}^{3}$ 'lük taşıma aracının sefer başına en yüksek 6,6 ton atık taşıdığı tespit edilmiştir. Diğer 2, 3 ve 4 nolu 13 m³'lük araçların sefer başına ortalama topladıkları atık miktarları 2,5 ton ile 4,8 ton arasında değișmektedir. Aynı tașıma hacmine sahip araçlarla çok farklı miktarlarda atık toplaması yapıldığı burada görülmektedir. Toplama ve taşımanın optimize edilmesi araçların en verimli kullanımını sağlayacaktır. Bunun yanında, $7 \mathrm{~m}^{3}$ lük araçların sefer başına topladıkları ortalama atık miktarları çok fazla

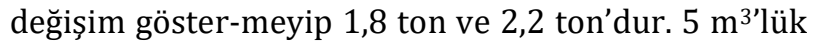
aracın ortalama sefer başına topladığı atık miktarı ise 1,75 ton'dur. $6 \mathrm{~m}^{3}$ 'lük aracın kaç sefer yaptığı ve ne kadar atık topladığı tespit edilemediği için, bu araçla alakalı sefer başına ortalama toplanan atık miktarı hesaplanamamıştır.

Çalışma süresince yaklaşık 14.919 km mesafe yapılarak toplam 1405 ton evsel atık toplanıp transfer istasyonuna taşınmıştır. $13 \mathrm{~m}^{3}$ 'lük araçların aylık toplam yaptığı mesafeler 871 km ile 2084 km arasında değişmekte olup bu araçların yaptığı aylık toplam mesafe $8334 \mathrm{~km}$ 'dir. Toplama için yapılan mesafenin \%56'llk kısmı $13 \quad \mathrm{~m}^{3}$ 'lük araçlarlayapılmıştır. $7 \mathrm{~m}^{3}$ lük araçlar için bu mesafeler $1505 \mathrm{~km}$ ile $2231 \mathrm{~km}$ arasındadır. $5 \mathrm{~m}^{3}$ ’ük araç toplam $463 \mathrm{~km}$ mesafe yapmıştır. $13 \mathrm{~m}^{3}$ lük araçların sefer başına yaptıkları mesafeler $31 \mathrm{~km}$ ile $42 \mathrm{~km}$ arasında değişirken, $7 \mathrm{~m}^{3}$ 'lük araçlar için bu mesafeler $30 \mathrm{~km}$ ile $45 \mathrm{~km}$ arasındadır. $13 \mathrm{~m}^{3}$ ve 7 $\mathrm{m}^{3}$ 'lük araçların sefer başına yaptıkları mesafeler hemen hemen aynıdır. Sefer başına yapılan en düşük

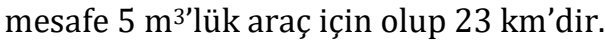

Ayrıca toplama ve taşıma verimliliğinin tespit edilip karşılaştırılabilmesi için 1 ton evsel atığın toplanıp 1 km taşınması için ne kadar dizel yakıt kullanıldığı hesaplanmış ve yine Tablo 1 . de verilmiştir. 13 $\mathrm{m}^{3}$ 'lük araçlar için, 1 nolu araç 2,52 lt/ton-km değeri ile en verimli toplama ve taşımayı yaparken, 4 nolu araç 4,88 lt/ton-km ile en verimsiz araçtır. $7 \mathrm{~m}^{3}$ 'lük araçlar için bu değer 4,80 lt/ton-km ile 5,88 lt/ton$\mathrm{km}$ arasın-dadır. $5 \mathrm{~m}^{3}$ lük araç için $2 \mathrm{lt} /$ ton-km'dir. $5 \mathrm{~m}^{3}$ 'lük aracın motor gücünün düşük olması ve sadece belli noktalardan yüksek miktarlarda evsel atık toplaması bu düşük değeri oluşturmuştur. Bu değerlerin yüksek olduğu araçlar için birçok toplama noktasına uğradıkları ve bu noktalarda uzun rölantide çalıştıkları yorumları yapılabilir. Araç bazında bu değerlerin düşürülmesi hem verimlilik sağlayacak hem de daha az GHG emisyonlarının oluşuma katkı sağlayacaktır.

Araçların oluşturdukları GHG emisyonları tamamen tüketilen yakıt miktarı ile alakalı olup 0,22 ton $\mathrm{CO}_{2}$-eş ile 3,26 ton $\mathrm{CO}_{2}$-eş arasında değişmektedir. 10 aracın aylık toplam oluşturduğu GHG miktarı 18,68 ton $\mathrm{CO}_{2}$ eş'dir. Diğer bir deyişle bu değer Hayrabolu ilçesinin 
52 mahallesinden evsel atık toplama sonucu oluşan aylık toplam GHG değeridir. İlaveten her araç için ortalama aylık GWF değerleri hesaplanmış ve Tablo 1 'in en son sütununda verilmiștir. Şekil 2. de her bir toplama aracının ortama aylık GWF'leri verilmiştir. En düşük GWF, 6,29 kg CO 2 -eş/ton-atık ile $5 \mathrm{~m}^{3}$ ’ük motor gücü düşük araca aittir. $13 \mathrm{~m}^{3}$ lük araçlar için bu değer $8,10 \mathrm{~kg} \mathrm{CO}$-eş/ton-atık ile $15,47 \mathrm{~kg} \mathrm{CO} \mathrm{CO}_{2}$ eş/ton-atık gibi geniş bir aralıkta değişmektedir. 7 $\mathrm{m}^{3}$ 'lük araçlar içinse $15,33 \mathrm{~kg} \mathrm{CO}_{2}$-eş/ton-atık ile $18,82 \mathrm{~kg} \mathrm{CO}$-eş/ton-atık gibi çok yüksek değerlere sahiptir. Bu sonuçlardan $7 \mathrm{~m}^{3}$ 'ük araçların doluluk oranlarının az olduğu yorumu rahatlıkla yapılabilir. 1 ton evsel atığın $1 \mathrm{~km}$ mesafeye taşınması için araç bazında tüketilen yakıt miktarları ile araç bazında hesaplanan GWF değerleri arasında doğrudan bir ilişki vardır. $\mathrm{Bu}$ değerlerden herhangi birinin hesaplanması diğeri hakkında bilgi verebilmektedir. Her araç GWF değerlerinin hesaplanmasının yanı sıra, Hayrabolu için ortalama bir GWF değeri; toplam aylık GHG değerinin toplam aylık evsel atık miktarına bölünmesiyle $13,30 \mathrm{~kg} \quad \mathrm{CO}_{2}$-eş/ton-atık olarak hesaplanmıştır.

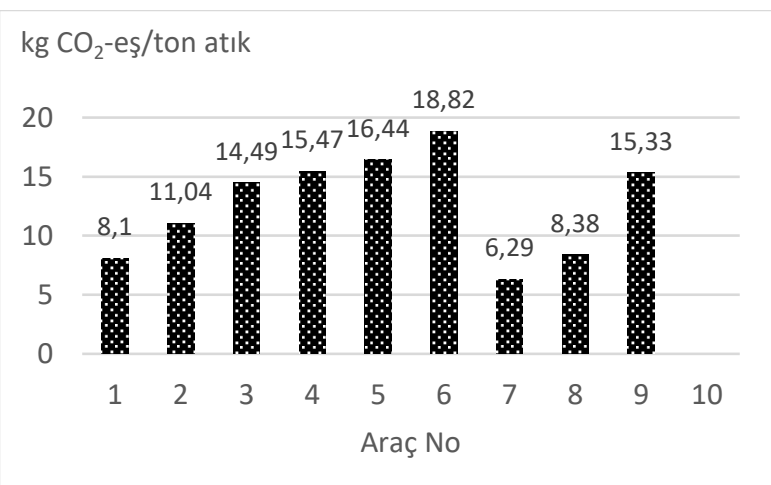

Şekil 2. Araçlardan kaynaklanan GWF değerleri

Şekil 3. de Hayrabolu için hesaplanmış ortalama GWF değeri bazı diğer şehirlerle karşılaştırılmıştır. Uluslararası literatüre bakıldığında Larsen ve diğ. [4] Danimarka'nın Aarhus şehri için ortalama GWF değerini $30 \mathrm{~kg} \mathrm{CO}$-eş/ton-atık olarak vermiştir. Yine Larsen ve diğ. [8] aynı şehir için benzer bir çalışma yapmış ve GWF'lerin 9,3-9,9 kg CO 2 -eş/ton-atık arasında değiștiğini tespit etmişlerdir. Fisher [10], Skovgaard ve diğ. [11], Smith ve diğ. [9] bazı Avrupa şehirleri için GWF değerlerini hesaplamış ve 5-17 kg $\mathrm{CO}_{2}$-eş/ton-atık arasında vermişlerdir. Benzer olarak Zhao ve diğ. [19], Çin'in Tianjin şehri için GWF değerini $15 \mathrm{~kg} \mathrm{CO}_{2}$-eş/ton-atık olarak tespit etmişlerdir. Hayrabolu için bu değer $13,30 \mathrm{~kg} \mathrm{CO} \mathrm{CO}_{2}$ eş/ton-atık'dır. Korkut ve diğ. [5] GWF değerini İstanbul için ortalama $7,7 \mathrm{~kg} \mathrm{CO}$-eş/ton-atık olarak tespit edilmiştir. İstanbul için bu değerin düşük olmasının sebebi yüksek nüfus yoğunluğu ve toplama mesafelerinin kısa olması olarak gösterilebilir.

Korkut ve diğ. [5], GWF'leri Çatalca'da en yüksek 15,2 $\mathrm{kg} \mathrm{CO}$-eş/ton-atık ve Şile'de ise $10,44 \mathrm{~kg} \mathrm{CO}$-eş/tonatık olarak hesaplamışlardır. Hayrabolu için tespit edilen bu değerin, Çatalca ve Şile ilçeleri için tespit edilen değerler aralığında kalması bu ilçelerin toplama ve taşıma karakterlerinin birbirine benzediğini göstermektedir. Hayrabolu için tespit edilen değerin, Avrupa ve Çin'deki bazı şehirler için tespit edilen GWF değerlerine mertebesinde olması, toplama işleminin normal yapıldığı, fakat yine de veriminin artırılabileceğini ortaya koymaktadır. Bunun içinde toplama ve taşıma mutlaka optimize edilmelidir.

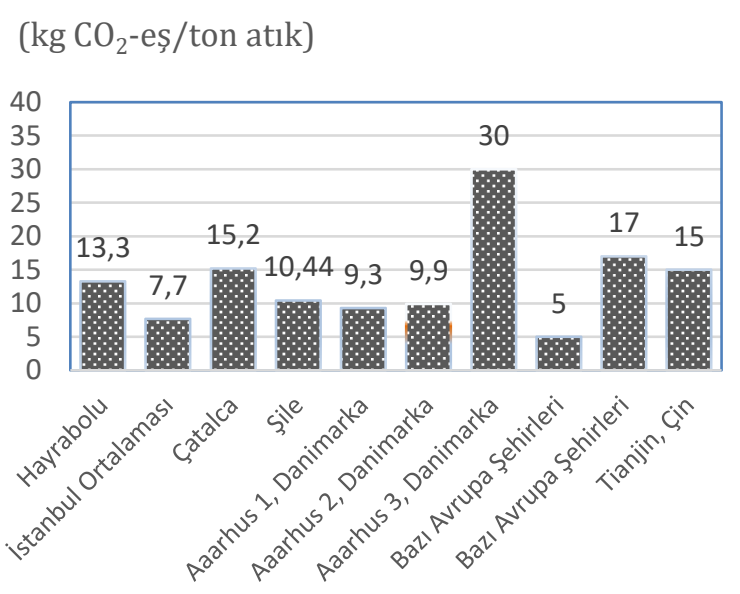

Şekil 3. GWF değerlerinin Hayrabolu ve diğer bazı șehirler için karşılaştırılması

Hayrabolu ilçesinin her mahallesinin toplam yüzeysel yerleşim alanı, nüfusu, atık alınan nokta sayısı, aylık toplam toplanan atık miktarı ve kişi başına oluşan atık miktarları Tablo 2.de ayrıntılı olarak verilmiştir. Bu tabloda ayrıca, her mahalle için GHG emisyonları ve mahallelerdeki kişi başına oluşan GHG'ler hesaplanmıştır. Bunun için, araçların faaliyetleri sonucu hesaplanmış ortalama GWF değeri olan 13,30 $\mathrm{kg} \mathrm{CO}_{2}$-eş/ton-atık, her mahalleden toplanan ton cinsinden atık miktarı ile çarpılmak suretiyle her mahallenin meydana getirdiği GHG emisyonları hesaplanmıştır.

İlçenin en fazla nüfusa sahip mahalleleri merkez mahalleleridir. Bu mahalleler; İlyas 6700, Aydınevler 6150, Hisar 3019, ve Kahya 2154 kişi nüfusa sahiptir. Eski belde olan ve şimdi mahalle olan Çerkezmüsellim 2501 ve Şalgamlı 1354 kişi nüfusa sahiptir. $\mathrm{Bu} 6$ mahallenin nüfusu toplam ilçe nüfusunun \%68'ini oluşturmaktadır. En kalabalık olan bu 6 mahalleden toplanan evsel atık miktarı 1058,2 ton olup bütün 52 mahalleden toplanan atıkların \%77'sine oluşturmuştur. \%23'lük kısım eski köy vasıflı diğer 46 mahalleden toplanmıştır. Atıkların çoğunluğu nüfusun yüksek olduğu 4 merkez ve 2 eski belde olan mahallelerden toplanmıştır. Atık alınan toplama noktalarının yarısından fazlası yine bu 6 mahallededir.

Hayrabolu'nun bütün mahalleleri için ortalama kişi başına toplanan günlük atık miktarı, Tablo 2. de verilen ilçeden bir ay boyunca toplanan atık miktarının toplam nüfusa bölünmesiyle 1,42 kg/kişigün olarak bulunmuştur. Ayrıca, kişi başına toplanan 
atık miktarları her mahalle için ayrı ayrı hesaplanıp değerlendirilmiştir. Buna göre, eski belde olan Çerkezmüsellim ve Şalgamlı mahallelerinden sırasıyla kişi başına günlük 4,38 $\mathrm{kg}$ ve $2,22 \mathrm{~kg}$ atık toplanmıştır. Bu değerler günlük kişi başına toplanan en yüksek evsel atık miktarını meydana getirmiş ve ortalamanın üstündedir. Bu yüksek değerlerin sebebi olarak evsel atıklara tarımsal ve hayvancılığa bağlı atıkların karıștığı rahatlıkla söylenebilir. Genelde tarım ve hayvancılığın yaygın olduğu Hayrabolu ilçesinde merkez mahalleleri dişında oluşan tarım ve hayvancılık atıkları tarım arazilerinde değerlendirilirken, merkez mahallelerde bu atıklar evsel atıklarla birlikte toplanmaktadır. Merkez mahallelerde ticaret ve sanayi faaliyetleri de bulunduğundan kiși başına günlük atık miktarı fazla çlkabilmektedir. Merkez mahallelerinden Hisar için 0,53 kg/kişi.gün ve Aydınevler için 1,52 kg/kişi.gün değerleri hesap edilmiştir. Merkez mahallelerde hem nüfusun fazla olması hem de toplanan atık miktarının fazla olmasına rağmen kişi bașına toplanan günlük atık miktarı mahalleye bağlı olarak genel ortalamaya yakın veya altında çıkmaktadır. 4 merkez mahallesi ve eski belde olan 2 mahallenin dişında kalan tarım ve hayvancılığın yaygın olduğu mahallelerden toplanan ortalama kişi başına günlük evsel atık miktarı 1,07 kg'dır. Hacılı mahallesinden kişi başına günlük 2,62 kg atık toplanmıştır. Bu değer merkez dışı mahallelerin ortalamasının yaklaşık 2,5 katı olup aynı zamanda en yüksek değerdir. Merkez dıșı olan bir mahallede bu kadar yüksek bir değerin sebebi olarak evsel atıklara Çerkezmüsellim ve Şalgamlı'da olduğu gibi yüksek miktarda tarım ve hayvancılığa bağlı atıkların karıștığını göstermiştir. Diğer taraftan Cambazdere, Aydınlar gibi mahallelerde 0,4-0,5 kg/kişi.gün gibi düşük veya çok düşük kişi başına atık oluşumu tespit edilmiştir. Bu düşük değerler evsel atıklara tarım ve hayvancılık sonucu oluşan atıkların karıştırılmadığını göstermektedir. Merkez ve merkez dışı mahalleler için ayrı ayrı atık karekterizasyonunun yapılması bu konuda daha doğru yorumlamaların yapılmasına büyük fayda sağlayacaktır.

Her mahalleden toplanan aylık atık miktarları yukarıda toplama araçları için ortalama olarak hesap edilmiş GWF değeri olan 13,30 kg CO 2 -eş/ton-atık ile çarpılarak her mahallenin oluşturduğu toplam aylık GHG emisyonları hesap edilmiş ve Tablo 2. de verilmiştir. Çerkezmüsellim gibi en yüksek atık miktarının toplandığı mahallelerde GHG, $4373 \mathrm{~kg}$ $\mathrm{CO}_{2}$-eş gibi en yüksek değere çlkarken, Cambazdere, Bayramşah, Duğcalı, Fahrioğlu, Hacılı, İsmailli, Muzruplu, Parmaksız, Umurça, Yörgüç ve Yörükler gibi en düşük atık miktarlarının toplandığı mahallelerde 30-40 kg CO 2 -eş gibi en düşük değerlere ulaşmaktadır.

Çerkezmüsellim mahallesi en yüksek GHG değerine sahip olup, daha sonraki en yüksek değerler merkez mahalleleri ve Şalgamlı mahallesi için 3724 kg CO 2 -eş ile $638 \mathrm{~kg} \mathrm{CO}$-eş arasında değişmektedir. $\mathrm{Bu} 6$ mahalleden atık toplamaya bağlı olarak oluşan toplam GHG miktarı $14.074 \mathrm{kgCO}_{2}$-eş'ne eşittir. Diğer 46 mahalle için GHG miktarları 527 kg CO 2 -eş ile 29 kg CO 2 -eş gibi geniş bir aralıkta değişmektedir. $\mathrm{Bu} 46$ mahalle toplam $4195 \mathrm{~kg} \mathrm{CO}$-eş GHG oluşturmuştur. Hayrabolu'da atık toplama sonucu toplam aylık $18.269 \mathrm{~kg} \mathrm{CO}_{2}$-eş $\left(18,27\right.$ ton $\mathrm{CO}_{2}$-eş $)$ GHG oluşmaktadır. Toplanan atık miktarlarına paralel olarak, toplam GHG'nin \%77'si nüfus ve toplanan atık miktarlarının en yüksek olduğu 6 mahallede oluşurken diğer \%23'lük kısmı diğer 46 mahallede olușmaktadır. Nüfusun yüksek olduğu mahallelerde ortalama GHG 2346 kg CO -eş iken, nüfusun düşük olduğu 46 mahallede ortalama GHG 91 kg CO 2 -eş'dir. Görüldüğü gibi merkez ve merkez olmayan mahalleler arasında GHG oluşumu bakımından büyük farklılıklar oluşmuştur. Bu sebeple bütün mahalleleri aynı kategoride karşılaştırmak yerine, nüfus çokluğuna göre sınıflandırılmalı ve karşılaştırılmalıdır.

Toplam aylık 18,27 ton $\mathrm{CO}_{2}$-eş GHG değeri yıllık yaklaşık toplam 219 ton $\mathrm{CO}_{2}$-eş'ne karşılık gelmektedir. $\mathrm{Bu}$ yıllık değer, Nafiz E. Korkut ve diğ.'nin [5] makalesindeki İstanbul ilçeleri için hesaplanan değerlerle karşılaștırıldığında, hem nüfus hem de oluşturdukları GHG emisyonlarına benzerlik bakımından Şile ilçesine benzer değerler vermektedir. Şile'nin 2015 ilçe nüfusu 33.477 ve oluşturduğu yıllık GHG değeri 194 ton $\mathrm{CO}_{2}$-eş iken Hayrabolu'nun 2017 nüfusu 32.157 ve oluşturduğu yıllık GHG değeri 219 ton $\mathrm{CO}_{2}$-eș'dir. Yine bu değer İstanbul'un diğer düşük nüfuslu bir ilçesi olan Çatalca ile de karşılaştırılabilir. Bahse konu makalede Çatalca'nın nüfusu 67.329 ve oluşturduğu senelik GHG emisyonu 425 ton $\mathrm{CO}_{2}$-eş'dir. Çatalca'nın nüfusu Hayrabolu'nun hemen hemen iki katında biraz fazla olup Hayrabolu ilçesinin iki katından biraz fazla GHG oluşturmaktadır. Bu sebeple nüfus ile atık toplamaya bağlı oluşan GHG arasında doğrusal ilişki kurulabilir. İstanbul'un diğer ilçelerinin nüfusları Hayrabolu'dan çok fazla ve yoğun olmasından dolayı bu ilçelerle Hayrabolu'yu GHG'yi göz önüne alarak karşılaştırmak uygun görülmemiştir.

Her mahalle için kişi başına oluşan GHG miktarları yine Tablo 2. de verilmiştir. Bütün mahalleler için ortalama kişi başına değer $0,47 \mathrm{~kg} \mathrm{CO}$-eş olarak hesaplanmıștır. Kişi başına oluşan en düşük GHG miktarı Cambazdere mahallesi için 0,17 kg CO 2 -eş'dir. $\mathrm{Bu}$ değerin en yükseği Çerkezmüsellim mahallesi için $1,75 \mathrm{~kg} \mathrm{CO}$-eş'dir. Korkut ve diğ. [5] İstanbul için ortalama kişi başına oluşan GHG miktarını 3,16 olarak hesaplamıştır. İstanbul'da kişi başına meydana gelen atık miktarı 1,12 kg iken Hayrabolu'da ise bu değer 1,46 kg'dır. Hayrabolu'da kişi başına toplanan atık fazla olmasına rağmen, kişi başına oluşan GHG İstanbul'dan çok daha azdır. İstanbul'da bu değer ilçeden ilçeye büyük değişiklikler göstermektedir.

Tablo 2. Hayrabolu mahalleleri için hesaplanmış GHG ve kişi bașı GHG değerleri 


\begin{tabular}{|c|c|c|c|c|c|c|c|}
\hline $\begin{array}{l}\text { Yerleşim adı } \\
\text { (Mahalle) }\end{array}$ & $\begin{array}{l}\text { Yerleşim } \\
\text { alanı } \\
\left(\mathrm{km}^{2}\right)\end{array}$ & $\begin{array}{l}\text { Nüfus } \\
\text { (kişi) }\end{array}$ & $\begin{array}{l}\text { Atık alınan } \\
\text { nokta sayısı }\end{array}$ & $\begin{array}{l}\text { Aylık top-lanan } \\
\text { atık miktarı } \\
\text { (ton) }\end{array}$ & $\begin{array}{l}\text { Kişi başı atık } \\
\text { üretimi } \\
\text { (kg/kişi.gün) }\end{array}$ & $\begin{array}{l}\text { GHG emis- } \\
\text { yonu, } \\
\text { (kg CO} 2-e s ̧)\end{array}$ & $\begin{array}{l}\text { Kişi başı GHG } \\
\text { değerleri (kg } \\
\mathrm{CO}_{2} \text {-eş/kişi) }\end{array}$ \\
\hline Aydınevler & 16,42 & 6150 & 180 & 280,0 & 1,52 & 3724 & 0,61 \\
\hline Çerkezmüsellim & 55,08 & 2501 & 391 & 328,8 & 4,38 & 4373 & 1,75 \\
\hline Hisar & 22,34 & 3019 & 154 & 48,0 & 0,53 & 638 & 0,21 \\
\hline ilyas & 15,56 & 6700 & 171 & 260,0 & 1,29 & 3458 & 0,52 \\
\hline Kahya & 34,06 & 2154 & 87 & 52,0 & 0,80 & 692 & 0,32 \\
\hline Şalgamlı & 22,66 & 1344 & 221 & 89,4 & 2,22 & 1189 & 0,88 \\
\hline Ataköy & 0,44 & 211 & 15 & 5,0 & 0,79 & 67 & 0,32 \\
\hline Avluobası & 0,71 & 127 & 14 & 4,8 & 1,26 & 64 & 0,50 \\
\hline Aydınlar & 0,48 & 386 & 21 & 6,2 & 0,54 & 82 & 0,21 \\
\hline Bayramşah & 0,32 & 92 & 10 & 3,0 & 1,09 & 40 & 0,43 \\
\hline Buzağcı & 0,55 & 152 & 14 & 4,8 & 1,05 & 64 & 0,42 \\
\hline Büyükkarakarlı & 1,36 & 455 & 31 & 11,2 & 0,82 & 149 & 0,33 \\
\hline Cambazdere & 0,46 & 237 & 10 & 3,0 & 0,42 & 40 & 0,17 \\
\hline Canhıdır & 0,55 & 103 & 13 & 3,6 & 1,17 & 48 & 0,46 \\
\hline Çeneköy & 0,91 & 348 & 29 & 9,8 & 0,94 & 130 & 0,37 \\
\hline Çıkrıkçı & 0,57 & 324 & 26 & 9,2 & 0,95 & 122 & 0,38 \\
\hline Dambaslar & 0,57 & 324 & 21 & 7,2 & 0,74 & 96 & 0,30 \\
\hline Danişment & 0,51 & 351 & 31 & 10,2 & 0,97 & 136 & 0,39 \\
\hline Delibedir & 0,48 & 199 & 17 & 5,4 & 0,90 & 72 & 0,36 \\
\hline Duğcalı & 0,38 & 56 & 9 & 2,8 & 1,67 & 37 & 0,67 \\
\hline Emiryakup & 0,48 & 275 & 21 & 7,2 & 0,87 & 96 & 0,35 \\
\hline Fahrioğlu & 0,45 & 58 & 7 & 2,4 & 1,38 & 32 & 0,55 \\
\hline Hacılı & 0,27 & 28 & 6 & 2,2 & 2,62 & 29 & 1,05 \\
\hline Hasköy & 0,64 & 290 & 22 & 7,4 & 0,85 & 98 & 0,34 \\
\hline Hedeyli & 0,61 & 302 & 33 & 9,6 & 1,06 & 128 & 0,42 \\
\hline İsmailli & 0,34 & 69 & 9 & 2,4 & 1,16 & 32 & 0,46 \\
\hline Kabahöyük & 0,78 & 349 & 33 & 9,8 & 0,94 & 130 & 0,37 \\
\hline Kadriye & 1,18 & 328 & 23 & 8,6 & 0,87 & 114 & 0,35 \\
\hline Kandamış & 0,73 & 172 & 17 & 6,4 & 1,24 & 85 & 0,49 \\
\hline Karababa & 0,49 & 160 & 17 & 5,4 & 1,13 & 72 & 0,45 \\
\hline Karabürçek & 0,53 & 167 & 18 & 6,6 & 1,32 & 88 & 0,53 \\
\hline Karakavak & 0,63 & 236 & 33 & 10,6 & 1,50 & 141 & 0,60 \\
\hline Karayahşi & 0,40 & 181 & 15 & 5,0 & 0,92 & 67 & 0,37 \\
\hline Kemaller & 0,36 & 181 & 20 & 7,0 & 1,29 & 93 & 0,51 \\
\hline Kılıçlar & 0,66 & 124 & 17 & 5,4 & 1,45 & 72 & 0,58 \\
\hline Kurtdere & 0,38 & 156 & 15 & 5,0 & 1,07 & 67 & 0,43 \\
\hline Kutlugün & 0,40 & 266 & 20 & 7,0 & 0,88 & 93 & 0,35 \\
\hline Küçükkarakarlı & 0,66 & 89 & 14 & 4,8 & 1,80 & 64 & 0,72 \\
\hline Lahna & 1,01 & 768 & 54 & 39,6 & 1,72 & 527 & 0,69 \\
\hline Muzruplu & 10,59 & 125 & 7 & 2,4 & 0,64 & 32 & 0,26 \\
\hline Öreyköy & 0,32 & 127 & 12 & 2,8 & 0,73 & 37 & 0,29 \\
\hline Övenler & 0,43 & 155 & 17 & 5,4 & 1,16 & 72 & 0,46 \\
\hline Parmaksız & 0,44 & 87 & 10 & 3,0 & 1,15 & 40 & 0,46 \\
\hline Soylu & 0,98 & 497 & 45 & 16,0 & 1,07 & 213 & 0,43 \\
\hline Subaşı & 0,49 & 408 & 29 & 9,8 & 0,80 & 130 & 0,32 \\
\hline Susuzmüsellim & 0,44 & 220 & 24 & 8,8 & 1,33 & 117 & 0,53 \\
\hline Tatarlı & 0,57 & 245 & 22 & 7,4 & 1,01 & 98 & 0,40 \\
\hline Temrezli & 0,51 & 265 & 19 & 6,8 & 0,86 & 90 & 0,34 \\
\hline Umurbey & 0,48 & 176 & 16 & 5,2 & 0,98 & 69 & 0,39 \\
\hline Umurça & 0,31 & 126 & 10 & 3,0 & 0,79 & 40 & 0,32 \\
\hline Yörgüç & 0,34 & 184 & 11 & 3,2 & 0,58 & 43 & 0,23 \\
\hline Yörükler & 0,53 & 110 & 10 & 3,0 & 0,91 & 40 & 0,36 \\
\hline Toplam & 201,84 & 32.157 & 2.091 & 1.374 & & 18.269 & 23,99 \\
\hline
\end{tabular}

Örneğin, Bahçelievler ilçesi kişi başına 1,01 kg CO 2 -eş GHG değeri ile en düșük emisyon oluşturan ilçedir. Bu değerin yüksek olduğu ilçeler için mutlaka toplama 
optimizasyonu ve araç doluluk analizlerinin yapılması gerekmektedir. Buradaki çalışma da, Çerkezmüsellim ve buna benzer kişi başına GHG değerinin yüksek olduğu mahallelerde bu değerlerin düşürülmesi için toplama optimizasyonu ve araç doluluk analizleri yine yapılmalıdır. Bunlar GHG emisyonlarının toplamda azaltılmasına katkı sağlayacaktır.

Tablo 1'de araçların topladığı toplam atık miktarı 1405 ton/ay iken Tablo 2'de mahallelerden aylık toplanan atık miktarı ise yaklaşık 1374 ton/aydır. Aradaki yaklaşık 31 tonluk fark belediyenin yaptığ sokak, cadde ve pazar yeri gibi temizlik faaliyetlerinden oluşan miktardır. Bu miktar toplam GHG ve ortalama GWF hesaplamalarında göz önünde bulundurulmuştur.

\section{Tartışma ve Sonuç}

Aynı toplama ve taşıma kapasiteli araçlarla sefer başına toplanan atık miktarları araçtan araca büyük farklılıklar gösterebilmektedir. Hem verimliliğin artırılması ve ekonomi sağlanması hem de daha az GHG oluşturmak için, araçların mutlaka yüksek doluluk oranları ile çalıştırılması, sefer başına toplanan atık miktarlarının artırılması, en kısa güzergahların kullanılması ve toplama noktalarında en kısa sürelerin geçirmeleri gerekmektedir. Mahallelerin transfer istasyonuna uzaklıkları değişmektedir. Bu yüzden iyi planlama yapılması gereklidir. Bütün toplama güzergahları bir arada değerlendirilerek hem kısa hem de yüksek doluluk elde edilebilecek alternatifler kullanılmalıdır. Düşük yoğunluklu ve geniş yüzey alanına sahip mahallelerde toplama mesafeleri uzun olduğu için ton başına toplanan atıklar için harcanan yakıt fazla, dolayısı ile oluşan GHG emisyonları fazladır. $\mathrm{Bu}$ bölgelerde toplama işlemi iyi değerlendirilmelidir.

Atık toplama sırasında kaç yerde durularak atık yüklemesi yapıldığı, her durmada toplama aracına boşaltılan konteynır sayısı ve durmalar arasında gidilen mesafeler gibi detaylı bilgiler kullanılarak atık toplamada harcanan dizel yakıtın miktarını tespit etmeye yönelik bazı modeller geliștirilmiștir (der Boer ve diğ., [20]; Sonesson, [21]). Her atık toplama bölgesinin kendine ait farklı nüfus yoğunluğu, farklı yüzey alanları, konutların birbirine yakınlığı ve toplama noktaları arasında mesafelerin farklılığı gibi özellikleri mevcut olduğundan, her bölge için geliştirilen modellerin girdileri farklılık gösterebilir. $\mathrm{Bu}$ çalışmada tespit edilmiş tüketilen yakıt miktarları benzer modellere uygulanarak ve model parametreleri ayarlanarak geleceğe dönük hem yakıt tüketim hem de GHG tahminleri yapılabilir.

Şehirler için toplam GHG değerleri oluşan kirlilik boyutları hakkında bilgi vermekte ve uzmanların bu değerleri karşılaştırılıp, karar vermeleri kolaylaşmaktadır. Fakat GWF'lerin hesaplanıp karşılaştırılması, birim toplanan atık başına oluşan
GHG emisyonları verdiği için, değerlendirme yapma bakımından daha belirleyicidir. Bu bakımdan GWF değerlerinin göz önüne alınarak karşılaştırmalar yapılması GHG emisyonlarını göz önüne alarak yapılan değerlendirmelerden daha doğru olacaktır. Çünkü, değişik mahalleler için toplanan birim atık başına oluşan GHG emisyon değerleri GWF olarak ifade edilmektedir. Mahallelere giden toplama araçlarının her mahalle için ayrı ayrı yaptığı mesafelerin tespit edilmesiyle her mahallenin GWF değerleri hesaplanabilir. Bu zorluktan dolayı bu çalışmada, her mahalle için ayrı bir GWF değeri hesaplamak yerine toplama araçlarının toplam faaliyetleri sonunu ortalama bir GWF değeri bulunmuş ve bu değerden faydalanarak her mahallenin oluşturduğu GHG değerlerinin hesaplanmasında kullanılmıştır. Elde edilen sonuçlar hem gelecek yıllara ait tahminlerde kullanılacak hem de karşılaştırma yapma imkanı sunacaktır.

GHG emisyonlarının en yüksek olduğu mahalleler merkez ve eski belde olan 6 mahalle olup, nüfusun yoğun olduğu bu bölgelerde atık azaltma ve geri kazanma konusunda çalışmaların yapılması gerekir.

Ambalaj atıklarının ayrı toplanması için ayrı konteynerler cadde ve sokaklara yerleştirilmeli ve bu konuda halkı bilinçlendirici çalışmalar yapılmalıdır. Diğer taraftan eski köy statüsünde bulunan nüfus yoğunluğu düşük mahallelerde haftalık yapılan atık toplama tekrar değerlendirilmelidir. Her mahallenin transfer istasyonu ve depo sahasına mesafeleri hesaplanarak toplama ve taşımanın aşırı maliyetli olduğu mahallelerde yerinde bertaraf usulleri mutlaka değerlendirilmelidir. Uzun ve dağınık toplama noktalarının bulunduğu mahallelerde taşımayı dolayısıyla GHG emisyonlarını minimize edecek alternatifler değerlendirilmelidir. Bu konuda mutlaka fayda maliyet analizleri gerçekleştirilmelidir. İlçeye hizmet eden mevcut transfer istasyonuna ilaveten seçiminin uygun yapılacağı bir bölgeye personele ihtiyaç duymayacak basit bir transfer istasyonu daha yapılabilir. Bu toplama araçlarının hem tașıma için gittiği mesafeyi hem de sefer sayısını azaltacaktır. Böylece yakıt tasarrufu sağlanarak düşük GHG oluşumları meydana gelir. Daha verimli ve yakıt tasarruflu araçların kullanılması, fosil yakıtlar yerine doğalgaz veya elektrikli araçların toplama faaliyetlerinde yer alması, bütün sistemlerin yeniden değerlendirilmesine sebep olacaktır.

Tarım ve hayvancılığın yoğun olarak yapıldığı mahallelerde bu faaliyetlerden oluşan atıkların evsel atıklara karıștırılmayıp mutlaka farklı şekillerde değerlendirilmesi alternatifleri araştırılmalıdır. Hayrabolu da kış yaz nüfusu arasında değişim olup buna benzer bir çalışmanın tüm yıl boyunca yapılması, bütün toplama faaliyetinin ortaya konması bakımından önem taşımaktadır.

Hayrabolu için atık toplamadan kaynaklanan toplam GHG 18,70 ton- $\mathrm{CO}_{2}$-eş'dir. Bu toplam GHG değeri sadece toplamayı kapsamakta olup transfer 
istasyonlarından depo sahalarına taşımaları, özel atık taşımalarını, geri kazanılan maddelerin taşınımından oluşan GHG'leri göz önüne almamaktadır. Buna benzer yapılacak çalışmalarda toplama ve taşımanın bir arada ele alınması ve en düşük GHG ve GWF değerlerini veren alternatiflerin seçilmesi daha uygun olacaktır. Toplamayı en verimli hala getirirken transfer istasyonu ile depolama sahası arasındaki mesafe iyi değerlendirmelidir. Her mahalle için ayrı ayrı toplama ve taşıma mesafelerinin tespit edilmesi, o mahalle için yapılacak çalışmalarda daha doğru sonuçların elde edilmesini sağlayacaktır. Sistemde verimliliği artıracak iyileştirmelere sürekli dikkat edilmelidir. Toplama ve taşımanın bir arada değerlendirildiği çalışmalarda haliyle daha yüksek GWF değerleri ortaya çıkacaktır. Bütün şehirler için toplama ve taşıma kaynaklı emisyonların tespit edilmiş olması birbirleriyle karşılaştırma imkânı sağlayacaktır. Bunun için değişik senaryolar hazırlanarak birim atık başına toplama ve taşımadan kaynaklanan emisyonları düşürmek için gerekli çalışmalar yapılmalıdır. Böylece şehirler GHG azaltımı konusunda daha aktif rol oynayacaklardır.

\section{Teşekkür}

$\mathrm{Bu}$ çalışmanın gerçekleştirilmesi sürecinde ve sonrasında bilgilerin temini ve diğer konularda desteklerini esirgemeyen Hayrabolu Belediyesinin ilgili personeline teșekkürlerimi sunarım. Ayrıca, bu süreçte desteklerini esirgemeyen, İstanbul Teknik Üniversitesi, İnşaat Fakültesi, Çevre Mühendisliği Bölümü öğretim üyesi Prof. Dr. İbrahim Demir'e ve yardımlarından dolayı aynı bölümde asistanlık yapan Yük. Müh. Elif Maçin'e teşekkürlerimi sunarım.

\section{Kaynakça}

[1] Simonetto, E.O., Borenstein, D. 2007. A decision support system for the operational planning of solid waste collection. Waste Management, 27:1286-1297.

[2] Iriarte, A., Gabarrell, X., Rieradevall, J. 2009. LCA of selective waste collection systems in dense urban areas. Waste Management, 29: 903-914.

[3] Eisted, R., Larsen, A.W., Christensen, T.H. 2009. Collection, transfer and transport of waste: Accounting of greenhouse gases and global warming contribution. Waste Management and Research, 27: 738-745.

[4] Larsen, A.W., Vrgoc, M., Christensen, T.H. 2009. Diesel consumption in waste collection and transport and its environmental significance. Waste Management \& Research, 27: 652-659.

[5] Korkut, N.E., Yaman, C., Küçükağa, Y., Jaunich, M.K., Demir, İ. 2018. Greenhouse gas contribution of municipal solid waste collection: A case study in the city of Istanbul, Turkey. Waste Management \& Research, 36(2): 131139.
[6] Spielmann, M., Scholz, R.W. 2005. Life Cycle Inventories for Transport Services. Int Journal of LCA, 10 (1):85-94.

[7] Spielmann, M., Bauer, C., Dones, R. 2007. Transport services: Ecoinvent report no. 14. Dübendorf, Switzerland: Inventories, S.C.f.L.C. Available at: https://db.ecoinvent.org/ reports/14_ Transport.pdf (accessed 11 July 2017).

[8] Larsen, A.W., Merrild, H., Moller, J., Christensen, T.H. 2010. Waste collection systems for recyclables: an environmental and economic assessment for the municipality of Aarhus (Denmark). Waste Management, 30(5): 744-754.

[9] Smith, A., Brown, K., Ogilvie, S., Rushton, K., Bates, J. 2001. Waste management options and climate change: Final report to the European Commission. DG Environment.

[10] Fisher, K. 2006. Impact of Energy from Waste and Recycling Policy on UKGreenhouse Gas Emissions - Final Report. Oxford, UK., Available at: http://randd.defra.gov.uk/ Document.aspx Document=WR0609_5737_ FRP.pdf (accessed 11 July 2017).

[11] Skovgaard, M., Hedal, N., Villanueva, A. 2008. Municipal waste management and greenhouse gases. Copenhagen, Denmark, Management, E.T.C.o.R.a.W. Available at: http://orbit.dtu.dk/ fedora/objects/orbit:80479/datastreams/ file_3309363/content (accessed 11 July 2017).

[12] Salhofer, S., Schneider, F., Obersteiner, G. 2007. The ecological relevance of transport in waste disposal systems in Western Europe. Waste Management, 27: 47-57.

[13] ICF Consulting. 2005. Determination of the Impact of Waste Management Activities on Greenhouse Gas Emissions. Update. Toronto, Canada: ICF Consulting. Available at: http://www.rcbc.ca/files/u3/ICF-finalreport. pdf (accessed 11 July 2017).

[14] Metcalfe, P. 2008. Energy Audit of the Kerbside Recycling Services. Energy Audit Camden Report 3. Wolverhampton, UK. The London Borough of Camden.

[15] Facanha, C., Horvath, A. 2007. Evaluation of lifecycle air emission factors of freight transportation. Environmental Science \& Technology, 41: 7138-7144.

[16] Jaunich, M.K., Levis, J.W., Barlaz, M.A., DeCarolis, J.F. 2016a. Lifecycle process model for municipal solid waste collection. Journal of Environmental Engineering, 142 (8): 04016037.

[17] Jaunich, M.K., Levis, J.W., DeCarolis, J.F, Gaston, E.V., Barlaz, M.A., Bartelt-Hunt, S.L., Jones, E.G., Hauser, L., Jaikumar. R. 2016b. Characterization 
of municipal solid waste collection operations. Resources, Conservation and Recycling, 114: 92102.

[18] Fruergaard, T., Astrup, T., Ekvall, T. 2009. Energy use and recovery in waste management and implications for accounting of greenhouse gases and global warming contributions. Waste Management \& Research, 27:724-737.

[19] Zhao, W., van der Voet, E., Zhang, Y., Huppes, G. 2009. Life cycle assessment of municipal solid waste management with regard to greenhouse gas emissions: Case study of Tianjin, China.
Science of the Total Environment, 407: 15171526.

[20] der Boer, J., den Boer, E., Jager, J,. 2007. LCAIWM: A decision support tool for sustainability assessment of waste management systems. Waste Management, 27: 1032-1045.

[21] Sonesson, U. 2000. Modelling of waste collection-a general approach to calculate fuel consumption and time. Waste Management and Research, 18: 115-123. 